\title{
POSITIVE EFFECTS OF LEGUMES ON SOIL ORGANIC CARBON STORAGE DISAPPEAR AT HIGH LEGUME PROPORTION ACROSS A WIDE RANGE OF ENVIRONMENTAL CONDITIONS IN GRASSLANDS IN THE PYRENEES
}

\author{
Antonio Rodríguez ${ }^{1}$, Rosa Canals $^{2}$, and Maria-Teresa Sebastià ${ }^{1}$ \\ ${ }^{1}$ University of Lleida \\ ${ }^{2} \mathrm{UPNA}$
}

May 12, 2020

\begin{abstract}
Soil is the largest terrestrial carbon pool, making it crucial for climate change mitigation. To disentangle the relationships of plant guild diversity with soil organic carbon (SOC) storage at broad spatial scales, we applied diversity-interaction models to a regional grassland database. The questions were if: 1) positive effects of plant guild diversity on SOC at broad spatial scales are similar to experiments; 2) the enhancement of SOC by legumes is constant in natural grasslands; and 3) the effects of legumes on SOC depend on interactions with other guilds. SOC increased with legume proportion up to 15-20\%, then decreased, across broad spatial scales. Additionally, legume effects were enhanced when grasses were dominant, which could be related to the strong capacity of grasses for capturing nitrogen; grass carbon exudates; the balance symbiotic/non-symbiotic nitrogen. Our findings can facilitate the elaboration of regional and local strategies to ameliorate the soil capacity to absorb carbon.
\end{abstract}

\section{INTRODUCTION}

Soil carbon is highly relevant for climate change mitigation (Canadellet al. 2007) because it constitutes the largest carbon pool in terrestrial ecosystems (Batjes 1996). However, there is still much uncertainty regarding the relationship between soil carbon storage and ecosystem biota, including the role of biodiversity patterns and human activities (Schulze 2006; Soussana \& Lemaire 2014; Ali \& Yan 2017). According to current conceptual models, ecosystem goods and services -counting soil carbon sequestration- are expected to depend strongly on biodiversity components (Hooper et al. 2005; Diaz et al.2007; Hector \& Bagchi 2007; Kirwan et al. 2009; Suter et al. 2015; Connolly et al. 2018). However, most evidence comes from diversity function experiments, which might suggest important underlying mechanisms (Fornara \& Tilman 2008; Prommer et al.2019), but do not encompass the whole complexity encountered in real ecosystems. Although small-scale experiments indicate that the relationship between biodiversity and several ecosystem services might exist (Hector et al. 1999; Ribas et al. 2015), evidence about a positive association between soil carbon storage and plant diversity in nature is scarce (Hollingsworth et al. 2008; Wardle 2016).

In recent years, attempts have been made to clarify how plant taxonomic and functional diversity drive soil carbon at broad scales (Manninget al. 2015; Chen et al. 2018). In addition, plant functional types (PFT, Steneck, 2001; Blondel, 2003) were also found relevant for explaining soil carbon content in experiments (Fornara \& Tilman 2008; Lange et al. 2015) and local studies (Wiesmeieret al. 2019). 
There is an unsolved discussion about the relevance of plant functional types versus plant traits (or functional diversity) on ecosystem function (Lavorel \& Garnier 2002; Ricotta et al. 2016). Furthermore, some authors postulate that ecosystem function depends on the dominant plant species or functional type (Grime 1977) (e.g., grasses in grassland ecosystems (Strömberg \& Strömberg 2011). However, several studies indicate an important role of PFT diversity and non-dominant plant functional types on grassland functioning (Debouket al. 2015), including legumes (Spehn et al. 2002), and even in the absence of legumes (Cong et al., 2014).

Plant functional types can be described as guilds when defined in terms of resource use (Sebastià 2007) sensu Root (Root 1967), for animals). Furthermore, resource use can also be considered a relevant plant functional trait. Although every plant species can be considered to occupy a specific and unique point in the multivariate space of functional traits (Wayne \& Bazzaz 1991), and therefore their role in the ecosystem to be unique, plant guilds provide good summary representations for biodiversity-function analysis. Grasses are efficient in terms of light capture because their leaves are at vertical angles (Sebastià 2007), while the architecture of their roots made them efficient capturing soil N. Legumes can have access to symbiotically-fixed atmospheric N. Non-legume forbs present a variety of ports and (flat to obtuse) leaf angles, and cannot fix atmospheric N (Canals \& Sebastià 2000; Sebastià 2007; Sebastià \& Puig 2008). However, recently, legumes were found to be more active in terms of $\mathrm{CO}_{2}$ exchange per biomass unit compared with other guilds, including highly dominant grasses, and non-legume forbs (Ibañezet al. 2020).

Plant guild effects on soil carbon storage need to be studied at broad scales to understand how they work independently of broad scale abiotic variables, as it is being done for plant taxonomical and functional diversity (Manning et al. 2015; Carol Adair et al. 2018). Ecologists and modelers need this information to validate conceptual paradigms and generate new hypotheses contributing to the refinement of global mechanistic models. Land managers and policy-makers need it to establish priorities for conservation objectives.

Here, we aim to disentangle plant guild effects on soil organic carbon (SOC) in the Pyrenees, by modelling data from an extensive database generated from a survey of 98 natural grasslands. The survey included a variety of climates; different landscape positions; and a range of grazing management regimes. We applied the diversity-interaction modelling (DIM) approach (Kirwan et al. 2009), which allowed us to separate the identity and interaction effects of plant guilds. Taking into consideration that previous studies, carried out at narrower scales, found a crucial but contrasting role of legumes within the plant guilds (p.e. Fornara \& Tilman, 2008b; Lange et al., 2014), we aim at answering the following questions:

Do the effects of plant guilds on SOC in natural grasslands mirror those found in experimental systems?

Are enhancement effects of legumes on SOC stable across the range of proportions commonly found in natural grasslands (10-50\%)?

Do the effects of legume proportions depend on other plant guild proportions, including forbs and grasses?

\section{Methods}

\section{Study sites}

The set of data used in this study was extracted from the PASTUS Database (http://ecofun.ctfc.cat/?p=3538), which was compiled by the Laboratory of Functional Ecology and Global Change (ECOFUN) of the Forest Sciences Centre of Catalonia (CTFC) and the University of Lleida (UdL). We sourced a wealth of data of 98 grassland patches distributed across the Pyrenees (Fig. S1), which are located between 42 and $43^{\circ} \mathrm{N}$ latitude and between $-2.2^{\circ} \mathrm{W}$ and $3^{\circ} \mathrm{E}$ longitude. The sampled area extends along $290 \mathrm{~km}$ from east to west and has an altitudinal range of $1700 \mathrm{~m}$, encompassing a wide variety of temperate and cold-temperate climates, with different precipitation conditions, depending on altitude and geographical location from Mediterranean to Continental and Boreo-Alpine (de Lamo \& Sebastià, 2006; Rodríguez et al., 2018). Annual temperatures (MAT) range between 1 and $9.9{ }^{\circ} \mathrm{C}$ and annual precipitation values (MAP) between 960 and 2100 mm (Gottardi, 2009; Fick \& Hijmans, 2017).

\section{Sampling design}


Sampling in the PASTUS database was designed according to a stratified random scheme, where samples were selected at random within strata. This process was done using the software ArcMap 10 (ESRI, Redlands, CA, USA). The basis for randomization was the map of habitats of Catalonia 1:50000 (Carreras, J. \& Diego, 2006) for the Eastern and Central sectors, the map of habitats of Madres-Coronat 1:10000 (Penin, 1997) for the North-Eastern sector and the land use map of Navarra 1:25000 (Gobierno de Navarra, 2003) for the Western sectors. Four variables were initially considered for sampling stratification within each sector: altitude $(<1800 \mathrm{~m} ; 1800-2300 \mathrm{~m} ;>2300 \mathrm{~m})$, slope $\left(0-20^{\circ} ; 20-30^{\circ} ;>30^{\circ}\right)$, macrotopography (mountain top/southern-facing slope; valley bottom/northern-facing slope) and grazing management (sheep grazing; cattle grazing; mixed grazing). Accordingly, we determined a set of homogeneous grassland patches by crossing the stratification variable layers. Grassland patches were then listed by type and arranged within each list randomly to determine sampling priority. At least one to two replicates of each patch type were sampled.

In each sampled grassland patch, a $10 \times 10 \mathrm{~m} 2$ plot was systematically placed in the middle of each homogeneous grassland patch, including a particular plant community. Soils and vegetation were sampled inside this $100 \mathrm{~m} 2$ plot, and environmental variables assessed (see Rodríguez et al., (2018) for additional details about sampling design).

\section{Environmental abiotic predictors}

All the variables included in this study are listed in table S1. Climate variables were determined from Worldclim 2.0 (Fick \& Hijmans 2017). Based on previous modeling of SOC in grasslands in the Pyrenees (Rodríguez et al. 2020), we selected Mean Annual Temperature (MAT), Mean Annual Precipitation (MAP) and Mean Summer Precipitation (MSP). In addition, we included in the model the intra-annual difference of temperature (Temperature Seasonality Index of Sebastià (TSIS); Rodríguez et al., 2020), calculated as the difference between mean summer temperature (MST) and mean annual temperature.

Bedrock type was determined in the field and confirmed from the Geological Map (ICGC. 2007). Bedrock was categorized into three categories: basic (marls and calcareous rocks), acidic (mostly sandstones and slates) and mixed.

Topographical variables included: slope, aspect, macrotopography and microtopography. Slope and aspect were determined in the field by clinometer and compass respectively. Macrotopography included exposed (South- and East-facing slopes mountain tops) and protected (North- and West-facing slopes, valley bottoms) positions, while microtopography considered three positions: smooth areas, convexities and concavities.

Regarding grazing management variables, detailed surveys were carried out among farmers, shepherds and land managers. Two management variables were considered: grazing intensity and grazer type. Grazing intensity was determined by estimating livestock stocking rates measured as livestock units/ha (LU/ha), and treated as semi-quantitative variable with three categories (Sebastià et al. 2008): low (1: $<0.2 \mathrm{LU} / \mathrm{ha}$ ), medium (2: $0.2-0.4 \mathrm{LU} / \mathrm{ha}$ ) and high (3: up to $0.4 \mathrm{LU} / \mathrm{ha}$ ); a few samples corresponded to abandoned grasslands $(0 \mathrm{LU} / \mathrm{ha})$. Grazer type was categorized into three main types: sheep grazing, cattle grazing and mixed grazing. Mixed grazing included associations comprising small and big livestock, mainly sheep and cattle, and more rarely horses. Sheep flocks always included a few goats (Rodríguezet al. 2018).

\section{Environmental biotic predictors}

Plots of $10 \times 10 \mathrm{~m}^{2}$ were established in the middle of homogeneous grassland patches holding a given plant community (Canals \& Sebastià 2000; Sebastiá 2004). Aboveground biomass was estimated from herbage harvested in four $50 \times 50 \mathrm{~cm}$ quadrats placed in a $2 \times 2 \mathrm{~m}$ subplot within the $100 \mathrm{~m}^{2}$ plot. Plant guild biomass was determined in one of the four quadrats per plot by hand separation. Four guilds were sorted: C3 grasses, sedges, legumes and non-legume forbs (the latter including some sub-shrubs), following Sebastià (2007). Guild biomass was then oven-dried at $60^{\circ} \mathrm{C}$ to constant weight.

\section{SOC sampling and analysis}


In each plot, one soil core was extracted with a $5 \times 5 \mathrm{~cm}$ probe at $0-20 \mathrm{~cm}$ soil depth. Carbon content of the fine earth was determined by the elemental auto-analyzer. The organic $\mathrm{C}$ fraction was determined by subtracting inorganic $\mathrm{C}$ in the carbonates from the total C. Soil organic carbon stocks (SOC) in the upper $20 \mathrm{~cm}$ soil layer were then estimated taking into account the organic $\mathrm{C}$ concentration in the sample and its bulk density, and subtracting the coarse particle $(>2 \mathrm{~mm})$ content, following García-Pausas et al. (2007). See Rodriguez et al. 2020 for further details about SOC sampling and determination.

\section{Diversity-interaction model}

To disentangle plant guilds effects on SOC, we built a Diversity-Interaction Model (DIM) (Kirwan et al. 2009) in two steps. Preliminary normality tests (distribution histogram and normal Q-Q plot, and the Shapiro Wilk $\mathrm{W}$ test (Shapiro et al. 1968)) showed that the variable SOC was not normaly distributed (W $=0.948$; p-value $<0.001)$. We log-transformed SOC to prevent a breach of the normality assumption by the residuals of the models $(\mathrm{W}=0.99 ; \mathrm{p}$-value $=0.18)$. From now on, it should be understood that the mention of SOC in the context of modelling refers always to $\log (\mathrm{SOC})$.

As a first step, to control the wide climatic and topographical variability of the Pyrenees (Garcia-Pausas et al. 2007, 2017) we fitted a linear model (Legendre \& Legendre 1998) for SOC considering only environmental drivers other than plant guilds. We included both main effects and pair-wise interactions. We selected several candidate terms by a semi-automatic procedure by a genetic algorithm included in the $\mathrm{R}$ package glmulti (Calcagno \& Mazancourt 2010). We selected the best model including only main effects of the predictors, using SOC as the response variable. Then we modelled the residuals of that model with the same predictors to look for significant candidate level-two interaction terms. Once we obtained a set of candidate model terms (with both main effects and interactions), those were included into a single model on which we performed backward-forward selection. We used several methods to compare and determine the final model, including the corrected Akaike information criterion (AICc; (Symonds \& Moussalli 2011)), the adjusted determination coefficient $\left(\mathrm{R}_{\mathrm{adj}}{ }^{2}\right)$ and model comparison techniques with the "anova()" function in R, using Chi-square tests to test whether the reduction in the residual sum of squares was statistically significant.

At the second step, to complete the DIM, we added to our null model the guild proportion variables and the guild pair-wise interactions. Because all guild proportions sum 100\%, we built a model without intercept at this step (Kirwan et al. 2009). We discarded curved relationships between the model terms and SOC by comparing this final DIM model with the corresponding generalized interaction model (Connolly et al.2013) using a likelihood test (Chi-squared $=1.27 \times 10^{-3}$; p-value $=0.97$; Hothorn et al., 2019).

In order to show the effects of plant guilds we calculated the predicted effects of the model for all possible combinations of grasses, forbs and legumes with the emmeans package (Lenth et al. 2019), fixing the rest of the variables at their mean value. Sedges were fixed at $0 \%$ because of their low effects on SOC (Table 1 ), their low mean proportion $(2 \%)$ and to obtain clearer plots. We built a ternary plot with the ggtern package (Hamilton \& Ferry 2018) to show predicted SOC variation across plant guild proportions. We also plotted SOC variation across a legume proportion gradient under: 1) a balanced scenario where grasses and forbs accounted equal proportions; 2) a forb-dominance scenario where forb:grass proportions were 80:20; 3 ) a grass-dominance scenario were forb:grass proportion was 20:80; and 4) a co-dominance scenario where grasses and forbs accounted equal proportions (50:50), of the remaining proportion unaccounted by legumes.

\section{Results}

We used data from 98 grassland patches in the Pyrenees (Fig. S1) to build a Diversity Interaction model (DIM) able to disentangle the effect of plant guild proportions (identity effects) and pairwise interactions (guild interaction effects) after controlling the influence of a set of climate, bedrock, topography and livestock management predictors (Table S1). Model results and ternary plots showing the predicted SOC values across grass, legume and forb proportions (Table 1 and Fig. 1) revealed the complex role of legumes.

Legumes enhanced SOC storage when mixed with either grasses or forbs, but only at low to moderate legume proportions (Fig. 1). SOC storage increased with legume proportion, up to 15-20\% legumes, depending on 
neighbors (Fig. 2). At legume proportions above 15-20\%, SOCS decreased with increased legume proportion (Fig. 2).

The enhancement effect of legumes on SOC storage was higher for grasses than for forbs (Figs. $1 \& 2$ ). The strongest legume enhancement effects on SOC occurred when grasses were dominant and legume proportion was around 10-15\% (Fig. 2). When forbs were dominant, the enhancement effect of legumes on SOC storage was lower than in the grass-dominance or the grass:forb codominance scenarios, with peak values around 15$20 \%$ legumes (Figs $1 \& 2$ ). Thus, the SOC maximum peak with legume enhancement was higher and reached faster (at lower legume proportions) under grass dominance than under codominance and forb-dominance scenarios (Figs. 1 \& 2).

Differently to grass, legume and forb effects, the effect of sedge proportion on SOC was independent of the proportions of other plant guilds. However, this guild was rare and reached low proportions in the grasslands. Finally, we did not find significant interactions between plant guilds and other environmental SOC drivers, suggesting that the revealed diversity-function patterns held under the wide array of environmental conditions tested.

\section{Discussion}

Our study showed how plant guild proportions and their pairwise interactions drove SOC at regional scale, and additionally to other environmental factors including climate, bedrock topography or livestock management (Table 1). Grasses, forbs and legumes were the most determinant plant guilds for SOC in Pyrenean grasslands. Legumes had an enhancement effect on SOC storage but only at moderate proportions (Fig. 1). When legume proportions reached intermediate values, SOC started to decrease. This effect was sharper at increasing grass proportions and more moderate at increasing forb proportions (Fig. 2).

SOC storage represents a complex equilibrium between primary production (inputs) and organic matter decomposition (outputs) that depends on multiple environmental factors including climate, soil texture and nutrients, and land management (Jenny, 1941; Schlesinger, 1977; Jackson et al., 2017). Our results demonstrate that some guilds at low proportions can have positive effects on SOC, but also that those enhancement effects can disappear or shift when the proportions among guilds are modified. In our DIM (Table $1 \&$ Fig. 1), the critical role of legumes on SOC is not surprising, since their symbiosis with rhizobia bacteria allow them to fix $\mathrm{N}_{2}$ from the atmosphere (McGrath et al. 2014), having large effects on $\mathrm{N}$ availability and supply (Zanetti et al. 1997; Spehn et al. 2002; Scherer-Lorenzenet al. 2003). These effects on soil N may alter SOC inputs and outputs among other ecosystem processes (Hector et al. 1999; Fornara \& Tilman 2008).

However, what is original in our work is the changing role of legumes on SOC storage depending on plant diversity and plant guild interactions. Former studies have reported positive, neutral and negative effects of legumes on SOC (Steinbeiss et al. 2008; Lange et al. 2015; Wu et al. 2017). Results from our DIM are novel because they suggest that those effects could be dependent on legume biomass proportion, as found in the case of Pyrenean natural grasslands. Nyfeler et al. $(2009,2011)$ found similar responses of plant $\mathrm{N}$ and yield to legume proportions in an experimental work, which can be behind the SOC-legume relationship we found. At low proportions (0-20\%), an increase in legumes enhanced noticeably the positive effect on SOC (Figs. 1 $\& 2$ ), which could be classified as a keystone effect (Mills 1993). Positive effects of legumes on SOC may have three different non-excluding explanations according to Zhao et al. (2014). Firstly, legumes would promote an increase in primary productivity of plant communities through increased $\mathrm{N}$ availability which would lead to an increase in SOC (Wu et al. 2017). Secondly, positive effects of legumes on SOC can be attributed to low $\mathrm{C} / \mathrm{N}$ ratios of legume residues (i.e. litter, root exudates...) more similar to soil microorganisms and soil organic matter than other plant residuals(Jensen et al.2012). Substrates with low $\mathrm{C} / \mathrm{N}$ ratios can reduce microbial $\mathrm{N}$ acquisition and increase their carbon use efficiency, facilitating humification processes and plant residues decomposition into soil organic matter (Spohn et al. 2016). Thirdly, N inputs through legumes may inhibit the production of oxidative enzymes to degrade the more recalcitrant compounds, leading to reduced ecosystem $\mathrm{CO}_{2}$ emissions and C losses (De Deyn et al. 2011; Spohn et al.2016).

On the other hand, in our study, when legume proportions were high, they had a negative effect on SOC 
according to our model (Figs $1 \& 2$ ). Negative effects of legumes on SOC stocks have been attributed to a decrease in community root biomass (Lange et al. 2015). Recent work by Prommer et al. (2019) suggested that the allocation of carbon to roots is less necessary at the community level when legumes are present, due to the increase of available $\mathrm{N}$ they fix. Furthermore, Henneron et al. (2019) found that the resource acquisitive strategy of legumes, with high photosynthetic activity and capacity and high root metabolic activity, exudation and death, may enhance soil microbial activity, depleting SOC stocks (i.e. rhizosphere priming effect; Kuzyakov, 2002). This explanation is also suggested by the findings in Ibañez et al. (2020), where high efficiency in $\mathrm{C}$ capture does not translate into high biomass in the grassland, We also suggest that, at some point, pathways for positive effects of legumes on SOC may be reversed. For instance, due to legumes' strategy of producing a more nutrient-rich and short-lived biomass than other plant guilds (Craine et al. 2002) high legume proportions may involve less total biomass in the long term, and low litter $\mathrm{C} / \mathrm{N}$ ratios could lead to higher mineralization rates and less carbon storage (Orwin et al. 2010). Indeed, this fits with findings by Ibañez et al. (2020) in grasslands in the Pyrenees, where higher legume proportions are associated with lower yield. Moreover, at high legume proportions, the additional $\mathrm{N}$ supply provided by $\mathrm{N}_{2}$ fixation may be inhibited because of the reduction of plant competition for soil $\mathrm{N}$ (Nyfeler et al. 2011), hence the mechanisms which may enhance SOC stocks at low legume proportions could be inhibited at high legume proportions.

Additionally, our model pointed out that the SOC levels were enhanced in grass-dominated grasslands (Figs. $1 \& 2$ ). This is an interesting finding since synergetic effects between grasses and legumes on SOC have been described for C4 grasses and not for C3 grasses (Fornara \& Tilman 2008; Yang et al. 2019), which is the main type of grass in the Pyrenees (Still et al. 2003). However, positive synergistic effects between grasses and legumes affecting $\mathrm{N}$ fixation and yield are well known (Kirwan et al. 2007; Nyfeler et al. 2011; Rasmussen et al. 2012; Schipanski \& Drinkwater 2012; Ribaset al. 2015; Suter et al. 2015). Pirhofer-Walzl et al. (2012) suggested that grasses could be especially good receivers of legume-derived Ndue to their fibrous root systems, which provide larger root surface and superficiality to grasses. Additionally, $\mathrm{N}_{2}$ fixation activity of legumes could be promoted by an increased demand for soil $\mathrm{N}$ on the whole ecosystem, as a consequence of an enhancement of grass root systems driven by the supply of atmospheric $\mathrm{N}_{2}$ fixed by legumes and transferred by litter, dead roots and exudates (Nyfeler et al. 2011). That enhancement of grass root systems also would allow grasses to acquire more $\mathrm{N}$ from non-symbiotic sources (Nyfeler et al. 2011; Suter et al.2015). Other mechanisms like optimization of the non-symbiotic $\mathrm{N}$ consumption by spatial (different root depths) and temporal (different growing seasons) niche partitioning could be behind legume-grass synergy on SOC (Van Ruijven \& Berendse 2005; Mueller et al. 2013). Grasses could also enhance SOC stocks since they are more adapted and tolerate grazing in a higher degree than forbs because of their evolutionary history linked to big ungulates (Coughenour 1985), and consequently they may present high regrowth rates and productivity in grasslands (Ganjurjav et al. 2019).

Most of the previous studies addressing plant guild effects on SOC of grasslands where carried out at local scales and/or employing experimental assemblages (Fornara \& Tilman 2008; Prommer et al.2019), not natural ecosystems as considered here. Moreover, most of these studies only considered the effect of plant guild richness and the presence or absence of the different plant guilds on SOC (Lange et al. 2015; Wu et al. 2017), although guild proportions effects have been described for other ecosystem functions like yield (Kirwanet al. 2007; Finn et al. 2013; Ribas et al. 2015). In contrast, what our model suggests is that: plant guild effects vary depending on their mass proportion in plant communities; some guilds, even in small proportions, can greatly enhance ecosystem function; those effects can be reversed at increasing proportions; and those observed effects stand over a wide range of grasslands and environmental conditions at regional scale. Hence, in addition to direct effects, shifts in plant guilds will have clear consequences on the rest of the biota (i.e. other plants, microbes), triggering a set of cascading effects in the ecosystem (Loranger-Merciris et al. 2006; Cornwellet al. 2008; De Deyn et al. 2008). We postulate that legume proportion determines the predominance of some processes over others, leading to SOC accumulation at moderate legume proportions and to SOC depletion at high legume proportions.

Our results are also relevant for functional ecology since they illustrate the power and usefulness of plant 
guilds to study keystone effects and interactions in ecosystems. In the last decades PFTs, or plant guild approaches have been described as inferior methods in comparison with continuous trait indexes (Mason et al. 2005; Funket al. 2017). However, these last methods are focused on testing concrete hypothesis, like the mass-ratio (Grime 1998; Diaz et al.2007) or niche complementarity (Villéger et al. 2008; de Belloet al. 2016) hypotheses. Conversely, modelling of plant guild effects using DIM allowed us to detect critical functional phenomena like keystone legume effects (Spehn et al. 2002) or guild interactions effects (Fry et al. 2014) on soil organic carbon storage. Legume effects in this study worked contrary to the mass-ratio hypothesis. Indeed, small proportions of legumes produced high effects on ecosystem function, which disappeared at high legume proportions.

To conclude, our DIM revealed that SOC storage in the Pyrenees not only depends on regional, landscape and local scale factors including climate and topography but on the contribution of the different plant functional guilds and interactions between the guilds, although we did not found interactions between plant guilds and other environmental predictors. In particular, legumes had a complex effect as they enhanced SOC stocks at low proportions and minimize them at high proportions. The magnitude of those effects depended on the relative composition of other guilds in the grassland. Legume and grass proportions had interactive effects on SOC. SOC maximums were found at low-moderate legume proportions in grass-dominated grasslands. Different effects of the ability of legumes for fixing atmospheric $\mathrm{N}$ and their high nutrient acquisition strategy probably were behind this pattern. Our results stress the importance of the keystone role of the $\mathrm{N}_{2}$ fixation rate of legumes on SOC stocks in natural grasslands and provide a strong argument for species diversity conservation efforts under climate change conditions. In addition, our findings can facilitate the elaboration of regional and local strategies to ameliorate the soil capacity to absorb carbon (Conant et al., 2017), contributing to the global effort to preserve terrestrial carbon pools. However, natural grasslands are not as tractable as agronomic systems, and direct management of plant guilds is not possible. Hence, further research about how herbivores affect plant guilds at broad scales is needed, as it is possibly the only way to manage plant guild proportions in natural grasslands.

\section{Acknowledgements}

We would like to express our thanks to the many people who collaborated in fieldwork, sample processing and data analysis over time. Research in this paper is based on the PASTUS database, which was compiled from different funding sources over time, the most relevant being: the EU Interreg III- A Programme (I3A4- 147- E) and the POCTEFA Programme/Interreg IV- A (FLUXPYR, EFA 34/08); the Spanish Science Foundation FECYT- MICINN (CARBOPAS: REN2002- 04300- C02- 01; CARBOAGROPAS: CGL200613555- C03- 03 and CAPAS: CGL2010- 22378- C03- 01); the Foundation Catalunya- La Pedrera and the Spanish Institute of Agronomical Research INIA (CARBOCLUS: SUM2006- 00029- C02- 0). This work was funded by the Spanish Science Foundation FECYT- MINECO (BIOGEI: GL2013- 49142- C2- 1- R) and the University of Lleida (PhD Fellowship to AR).

\section{Bibliography}

Ali, A. \& Yan, E.R. (2017). Relationships between biodiversity and carbon stocks in forest ecosystems: A systematic literature review. Trop. Ecol. , 58, 1-14.

Batjes, N.H. (1996). Total carbon and nitrogen in the soils of the world. Eur. J. Soil Sci. , 65, 10-21.

de Bello, F., Carmona, C.P., Lepš, J., Szava-Kovats, R. \& Pärtel, M. (2016). Functional diversity through the mean trait dissimilarity: resolving shortcomings with existing paradigms and algorithms. Oecologia , 180, 933-940.

Blondel, J. (2003). Guilds or functional groups: does it matter? Oikos , 100, 223-231.

Calcagno, V. \& Mazancourt, C. De. (2010). glmulti : An R Package for Easy Automated Model Selection with ( Generalized) Linear Models.J. Stat. Softw. , 34, 1-29.

Canadell, J.G., Le Quere, C., Raupach, M.R., Field, C.B., Buitenhuis, E.T., Ciais, P., et al. (2007). Contri- 
butions to accelerating atmospheric $\mathrm{CO} 2$ growth from economic activity, carbon intensity, and efficiency of natural sinks. Proc. Natl. Acad. Sci. U. S. A. , 104, 18866-70.

Canals, R.M. \& Sebastia, M.T. (2000). Analyzing mechanisms regulating diversity in rangelands through comparative studies: A case in the southwestern Pyrennees. Biodivers. Conserv. , 9, 965-984.

Carol Adair, E., Hooper, D.U., Paquette, A. \& Hungate, B.A. (2018). Ecosystem context illuminates conflicting roles of plant diversity in carbon storage. Ecol. Lett. , 21, 1604-1619.

Chen, S., Wang, W., Xu, W., Wang, Y., Wan, H., Chen, D., et al.(2018). Plant diversity enhances productivity and soil carbon storage.Proc. Natl. Acad. Sci. U. S. A., 115, 4027-4032.

Cong, W.-F., van Ruijven, J., Mommer, L., De Deyn, G.B., Berendse, F. \& Hoffland, E. (2014). Plant species richness promotes soil carbon and nitrogen stocks in grasslands without legumes. J. Ecol. , 102, $1163-1170$.

Connolly, J., Bell, T., Bolger, T., Brophy, C., Carnus, T., Finn, J.A., et al. (2013). An improved model to predict the effects of changing biodiversity levels on ecosystem function. J. Ecol. , 101, 344-355.

Connolly, J., Sebastia, M.T., Kirwan, L., Finn, J.A., Llurba, R., Suter, M., et al. (2018). Weed suppression greatly increased by plant diversity in intensively managed grasslands: A continental-scale experiment. $J$. Appl. Ecol. , 55, 852-862.

Cornwell, W.K., Cornelissen, J.H.C., Amatangelo, K., Dorrepaal, E., Eviner, V.T., Godoy, O., et al. (2008). Plant species traits are the predominant control on litter decomposition rates within biomes worldwide. Ecol. Lett. , 11, 1065-1071.

Coughenour, M.B. (1985). Graminoid responses to grazing by large herbivores: adaptations, exaptations, and interacting processes.Ann. - Missouri Bot. Gard. , 72, 852-863.

Craine, J.M., Tilman, D., Wedin, D., Reich, P., Tjoelker, M. \& Knops, J. (2002). Functional traits, productivity and effects on nitrogen cycling of 33 grassland species. Funct. Ecol. , 16, 563-574.

Debouk, H., de Bello, F. \& Sebastia, M.-T. (2015). Functional Trait Changes, Productivity Shifts and Vegetation Stability in Mountain Grasslands during a Short-Term Warming. PLoS One, 10, e0141899.

De Deyn, G.B., Cornelissen, J.H.C. \& Bardgett, R.D. (2008). Plant functional traits and soil carbon sequestration in contrasting biomes.Ecol. Lett. , 11, 516-531.

De Deyn, G.B., Shiel, R.S., Ostle, N.J., Mcnamara, N.P., Oakley, S., Young, I., et al. (2011). Additional carbon sequestration benefits of grassland diversity restoration. J. Appl. Ecol. , 48, 600-608.

Diaz, S., Lavorel, S., de Bello, F., Quetier, F., Grigulis, K., Robson, M., et al. (2007). Incorporating plant functional diversity effects in ecosystem service assessments. Proc. Natl. Acad. Sci. , 104, 20684-20689.

Fick, S.E. \& Hijmans, R.J. (2017). WorldClim 2: new 1-km spatial resolution climate surfaces for global land areas. Int. J. Climatol. , 37, 4302-4315.

Finn, J.A., Kirwan, L., Connolly, J., Sebastia, M.T., Helgadottir, A., Baadshaug, O.H., et al. (2013). Ecosystem function enhanced by combining four functional types of plant species in intensively managed grassland mixtures: A 3-year continental-scale field experiment.J. Appl. Ecol. , 50, 365-375.

Fornara, D.A. \& Tilman, D. (2008). Plant functional composition influences rates of soil carbon and nitrogen accumulation. J. Ecol. , 96, 314-322.

Fry, E.L., Power, S.A. \& Manning, P. (2014). Trait-based classification and manipulation of plant functional groups for biodiversity-ecosystem function experiments. J. Veg. Sci. , 25, 248-261.

Funk, J.L., Larson, J.E., Ames, G.M., Butterfield, B.J., Cavender-Bares, J., Firn, J., et al. (2017). Revisiting the Holy Grail: using plant functional traits to understand ecological processes. Biol. Rev. , 92, 1156-1173. 
Ganjurjav, H., Zhang, Y., Gornish, E.S., Hu, G., Li, Y., Wan, Y.,et al. (2019). Differential resistance and resilience of functional groups to livestock grazing maintain ecosystem stability in an alpine steppe on the Qinghai-Tibetan Plateau.

Garcia-Pausas, J., Casals, P., Camarero, L., Huguet, C., Sebastia, M.T., Thompson, R., et al. (2007). Soil organic carbon storage in mountain grasslands of the Pyrenees: Effects of climate and topography.Biogeochemistry, 82, 279-289.

Garcia-Pausas, J., Romanya, J., Montane, F., Rios, A.I., Taull, M., Rovira, P., et al. (2017). Are Soil Carbon Stocks in Mountain Grasslands Compromised by Land-Use Changes? In: High Mountain Conservation in a Changing World (eds. Catalan, J., Ninot, J.M. \& Aniz, M.M.). Springer International Publishing, Cham, pp. 207-230.

Grime, J.P. (1977). Evidence for the Existence of Three Primary Strategies in Plants and Its Relevance to Ecological and Evolutionary Theory. Am. Nat.

Grime, J.P. (1998). Benefits of plant diversity to ecosystems: immediate, filter and founder effects. J. Ecol. , 86, 902-910.

Hamilton, N.E. \& Ferry, M. (2018). ggtern: Ternary Diagrams Using ggplot2. J. Stat. Softw. , 87, 1-17.

Hector, A. \& Bagchi, R. (2007). Biodiversity and ecosystem multifunctionality. Nature , 448, 188-190.

Hector, A., Schmid, B., Beierkuhnlein, C., Caldeira, M.C., Diemer, M., Dimitrakopoulos, P.G., et al. (1999). Plant diversity and productivity experiments in european grasslands. Science, 286, 1123-7.

Henneron, L., Cros, C., Picon-Cochard, C., Rahimian, V. \& Fontaine, S. (2019). Plant economic strategies of grassland species control soil carbon dynamics through rhizodeposition. J. Ecol. , 1-18.

Hollingsworth, T.N., Schuur, E.A.G., Chapin, F.S. \& Walker, M.D. (2008). Plant Community Composition as a Predictor of Regional Soil Carbon Storage in Alaskan Boreal Black Spruce Ecosystems.Ecosystems , 11, 629-642.

Hooper, D.U., Chapin, F.S., Ewel, J.J., Hector, A., Inchausti, P., Lavorel, S., et al. (2005). Effects of biodiversity on ecosystem functioning: A consensus of current knowledge. Ecol. Monogr. , 75, 3-35.

Hothorn, T., Zeileis, A., Farebrother, R., Cummins, C., Millo, G., Mitchell, D., et al. (2019). Package "Imtest" Title Testing Linear Regression Models.

Ibanez, M., Altimir, N., Ribas, A., Eugster, W. \& Sebastia, M.T. (2020). Phenology and plant functional type dominance drive CO2 exchange in seminatural grasslands in the Pyrenees. J. Agric. Sci. , 1-12.

ICGC. (2007). Mapa geologic 1:50000 . Available at: http://betaportal.icgc.cat/visor/client_utfgrid_geo.html. Last accessed .

Jensen, E.S., Peoples, M.B., Boddey, R.M., Gresshoff, P.M., Hauggaard-Nielsen, H., J.R. Alves, B., et al. (2012). Legumes for mitigation of climate change and the provision of feedstock for biofuels and biorefineries. A review. Agron. Sustain. Dev. , 32, 329-364.

Kirwan, L., Connolly, R.M., Finn, J.A., Brophy, C., Luscher, A. \& Nyfeler, D. (2009). Diversity-Interaction Modeling : Estimating Contributions of Species Identities and Interactions to Ecosystem Function Sebastia Reviewed work ( s ): Published by : Ecological Society of America content in a trusted digital archive. We use information tec. Ecology , 90, 2032-2038.

Kirwan, L., Luscher, A., Sebastia, M.T., Finn, J.A., Collins, R.P., Porqueddu, C., et al. (2007). Evenness drives consistent diversity effects in intensive grassland systems across 28 European sites. J. Ecol. , 95, $530-539$.

Kuzyakov, Y. (2002). Review: Factors affecting rhizosphere priming effects. J. Plant Nutr. Soil Sci. , 165, 382-396. 
Lange, M., Eisenhauer, N., Sierra, C.A., Bessler, H., Engels, C., Griffiths, R.I., et al. (2015). Plant diversity increases soil microbial activity and soil carbon storage. Nat. Commun. , 6.

Lange, M., Habekost, M., Eisenhauer, N., Roscher, C., Bessler, H., Engels, C., et al. (2014). Biotic and abiotic properties mediating plant diversity effects on soil microbial communities in an experimental grassland. PLoS One, 9.

Lavorel, S. \& Garnier, E. (2002). Predicting changes in community composition and ecosystem functioning from plant traits: revisiting the Holy Grail . Funct. Ecol.

Legendre, P. \& Legendre, L. (1998). Numerical Ecology . 2nd edn. Amsterdam.

Lenth, R., Singmann, H., Love, J., Buerkne, P. \& Herve, M. (2019). Package 'emmeans.' Am. Stat.

Loranger-Merciris, G., Barthes, L., Gastine, A. \& Leadley, P. (2006). Rapid effects of plant species diversity and identity on soil microbial communities in experimental grassland ecosystems. Soil Biol. Biochem. , 38, $2336-2343$.

Manning, P., de Vries, F.T., Tallowin, J.R.B., Smith, R., Mortimer, S.R., Pilgrim, E.S., et al. (2015). Simple measures of climate, soil properties and plant traits predict national-scale grassland soil carbon stocks. $J$. Appl. Ecol. , 52, 1188-1196.

Mason, N.W.H., Mouillot, D., Lee, W.G. \& Wilson, J.B. (2005). Functional richness, functional evenness and functional divergence: the primary components of functional diversity. Oikos , 111, 112-118.

Mills, L.S. (1993). The Keystone-Species Concept in Ecology and Conservation Non-invasive Genetic Monitoring of Tigers in Bhutan View project Application of non-invasive genetic sampling to understand ecology of carnivores View project.

Mueller, K.E., Tilman, D., Fornara, D.A. \& Hobbie, S.E. (2013). Root depth distribution and the diversityproductivity relationship in a long-term grassland experiment. Ecology , 94, 787-793.

Nyfeler, D., Huguenin-Elie, O., Suter, M., Frossard, E., Connolly, J. \& Luscher, A. (2009). Strong mixture effects among four species in fertilized agricultural grassland led to persistent and consistent transgressive overyielding. J. Appl. Ecol. , 46, 683-691.

Nyfeler, D., Huguenin-Elie, O., Suter, M., Frossard, E. \& Luscher, A. (2011). Grass-legume mixtures can yield more nitrogen than legume pure stands due to mutual stimulation of nitrogen uptake from symbiotic and non-symbiotic sources. Agric. Ecosyst. Environ. , 140, 155-163.

Orwin, K.H., Buckland, S.M., Johnson, D., Turner, B.L., Smart, S., Oakley, S., et al. (2010). Linkages of plant traits to soil properties and the functioning of temperate grassland. J. Ecol. , 98, 1074-1083.

Pirhofer-Walzl, K., Rasmussen, J., Hogh-Jensen, H., Eriksen, J., Soegaard, K. \& Rasmussen, J. (2012). Nitrogen transfer from forage legumes to nine neighbouring plants in a multi-species grassland.Plant Soil, $350,71-84$.

Prommer, J., Walker, T.W.N., Wanek, W., Braun, J., Zezula, D., Hu, Y.,et al. (2019). Increased microbial growth, biomass and turnover drive soil organic carbon accumulation at higher plant diversity. Glob. Chang. Biol. , gcb.14777.

Rasmussen, J., Soegaard, K., Pirhofer-Walzl, K. \& Eriksen, J. (2012). N2-fixation and residual N effect of four legume species and four companion grass species. Eur. J. Agron., 36, 66-74.

Ribas, A., Llurba, R., Gouriveau, F., Altimir, N., Connolly, J. \& Sebastia, M.T. (2015). Plant identity and evenness affect yield and trace gas exchanges in forage mixtures. Plant Soil , 391, 93-108.

Ricotta, C., De Bello, F., Moretti, M., Caccianiga, M., Cerabolini, B.E.L. \& Pavoine, S. (2016). Measuring the functional redundancy of biological communities: a quantitative guide. 
Rodriguez, A., Canals, R.M., Plaixats, J., Albanell, E., Debouk, H., Garcia-Pausas, J., et al. (2020). Interactions between biogeochemical and management factors explain soil organic carbon in Pyrenean grasslands. Biogeosciences Discuss. , 1-56.

Rodriguez, A., de Lamo, X., Sebastia, M.-T. \& Sebastia, M.-T. (2018). Interactions between global change components drive plant species richness patterns within communities in mountain grasslands independetly of topography. J. Veg. Sci. , 29, 1029-1039.

Root, R.B. (1967). The Niche Exploitation Pattern of the Blue-Gray Gnatcatcher. Ecol. Monogr. , 37, $317-350$.

Van Ruijven, J. \& Berendse, F. (2005). Diversity-productivity relationships: Initial effects, long-term patterns, and underlying mechanisms. Proc. Natl. Acad. Sci. U. S. A., 102, 695-700.

Scherer-Lorenzen, M., Palmborg, C., Prinz, A. \& Schulze, E.D. (2003). The role of plant diversity and composition for nitrate leaching in grasslands. Ecology , 84, 1539-1552.

Schipanski, M.E. \& Drinkwater, L.E. (2012). Nitrogen fixation in annual and perennial legume-grass mixtures across a fertility gradient.Plant Soil , 357, 147-159.

Schulze, E.-D. (2006). Biological control of the terrestrial carbon sink * . Biogeosciences .

Sebastia, M.-T. (2004). Role of topography and soils in grassland structuring at the landscape and community scales. Basic Appl. Ecol. , 5, 331-346.

Sebastia, M.-T., de Bello, F., Puig, L. \& Taull, M. (2008). Grazing as a factor structuring grasslands in the Pyrenees. Appl. Veg. Sci., 11, 215-222.

Sebastia, M.T. (2007). Plant guilds drive biomass response to global warming and water availability in subalpine grassland. J. Appl. Ecol. , 44, 158-167.

Sebastia, M.T. \& Puig, L. (2008). Complex vegetation responses to soil disturbances in mountain grassland. Plant Ecol. , 199, 77-88.

Shapiro, S.S., Wilk, M.B. \& Chen, H.J. (1968). A comparative Study of Various Tests for Normality. J. Am. Stat. Assoc.

Soussana, J.F. \& Lemaire, G. (2014). Coupling carbon and nitrogen cycles for environmentally sustainable intensification of grasslands and crop-livestock systems. Agric. Ecosyst. Environ. , 190, 9-17.

Spehn, E.M., Scherer-Lorenzen, M., Schmid, B., Hector, A., Caldeira, M.C., Dimitrakopoulos, P.G., et al. (2002). The role of legumes as a component of biodiversity in a cross-European study of grassland biomass nitrogen. Oikos , 98, 205-218.

Spohn, M., Potsch, E.M., Eichorst, S.A., Woebken, D., Wanek, W. \& Richter, A. (2016). Soil microbial carbon use efficiency and biomass turnover in a long-term fertilization experiment in a temperate grassland. Soil Biol. Biochem. , 97, 168-175.

Steinbeiss, S., Bessler, H., Engels, C., Temperton, V.M., Buchmann, N., Roscher, C., et al. (2008). Plant diversity positively affects short-term soil carbon storage in experimental grasslands. Glob. Chang. Biol. , 14, 2937-2949.

Steneck, R.S. (2001). Functional Groups. Encycl. Biodivers. , 609-623.

Still, C.J., Berry, J.A., Collatz, G.J. \& DeFries, R.S. (2003). Global distribution of C 3 and C 4 vegetation: Carbon cycle implications. Global Biogeochem. Cycles , 17, 6-1-6-14.

Stromberg, C.A.E. \& Stromberg, S. (2011). Evolution of Grasses and Grassland Ecosystems. Annu. Rev. Earth Planet. Sci. is online earth.annualreviews.org, 39, 517-561. 
Suter, M., Connolly, J., Finn, J.A., Loges, R., Kirwan, L., Sebastia, M.T., et al. (2015). Nitrogen yield advantage from grass-legume mixtures is robust over a wide range of legume proportions and environmental conditions. Glob. Chang. Biol. , 21, 2424-2438.

Symonds, M.R.E. \& Moussalli, A. (2011). A brief guide to model selection, multimodel inference and model averaging in behavioural ecology using Akaike's information criterion. Behav. Ecol. Sociobiol. , 65, 13-21.

Villeger, S., Mason, N.W.H. \& Mouillot, D. (2008). New multidimensional functional diversity indices for a multifaceted framework in functional ecology. Ecology , 89, 2290-2301.

Wardle, D.A. (2016). Do experiments exploring plant diversity-ecosystem functioning relationships inform how biodiversity loss impacts natural ecosystems? J. Veg. Sci. , 27, 646-653.

Wayne, P.M. \& Bazzaz, F.A. (1991). Assessing diversity in plant communities: The importance of withinspecies variation. Trends Ecol. Evol.

Wiesmeier, M., Urbanski, L., Hobley, E., Lang, B., von Lutzow, M., Marin-Spiotta, E., et al. (2019). Soil organic carbon storage as a key function of soils - A review of drivers and indicators at various scales. Geoderma , 333, 149-162.

Wu, G., Liu, Y., Tian, F. \& Shi, Z. (2017). Legumes Functional Group Promotes Soil Organic Carbon and Nitrogen Storage by Increasing Plant Diversity. L. Degrad. Dev. , 28, 1336-1344.

Yang, Y., Tilman, D., Furey, G. \& Lehman, C. (2019). Soil carbon sequestration accelerated by restoration of grassland biodiversity. Nat. Commun. , 10, 718.

Zanetti, S., Hartwig, U.A., van Kessel, C., Luscher, A., Hebeisen, T., Frehner, M., et al. (1997). Does nitrogen nutrition restrict the CO 2 response of fertile grassland lacking legumes? Oecologia , 112, 17-25.

Zhao, J., Wang, X., Wang, X. \& Fu, S. (2014). Legume-soil interactions: legume addition enhances the complexity of the soil food web.Plant Soil , 385, 273-286. 

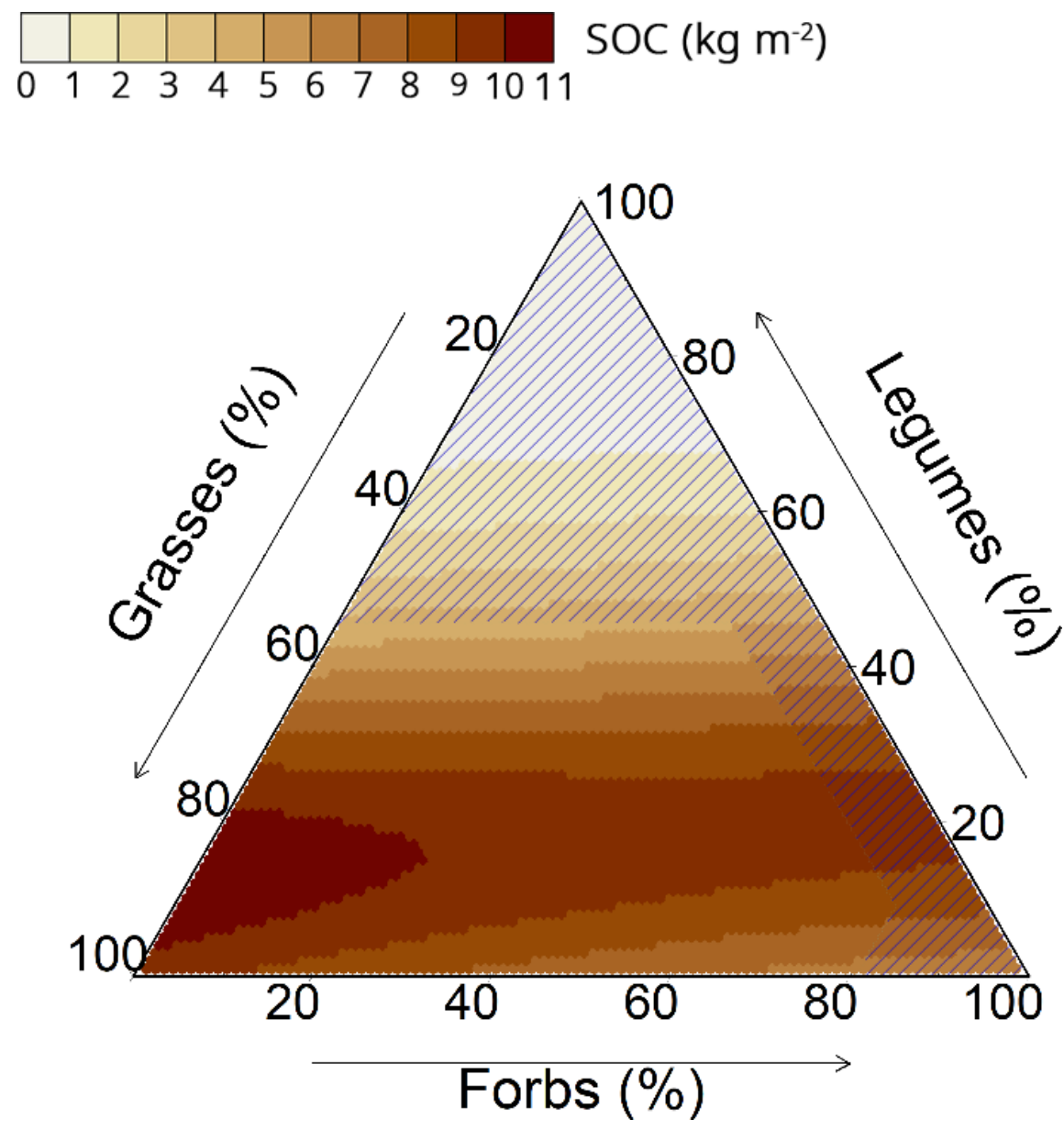

Figure 1: Ternary plot showing predicted SOC values at different guilt proportions. Striped areas correspond to extrapolated predictions, as those particular guild proportions were not present in the PASTUS database. Sedges were fixed at $0 \%$. Other variables in the model fixed at their mean value. 


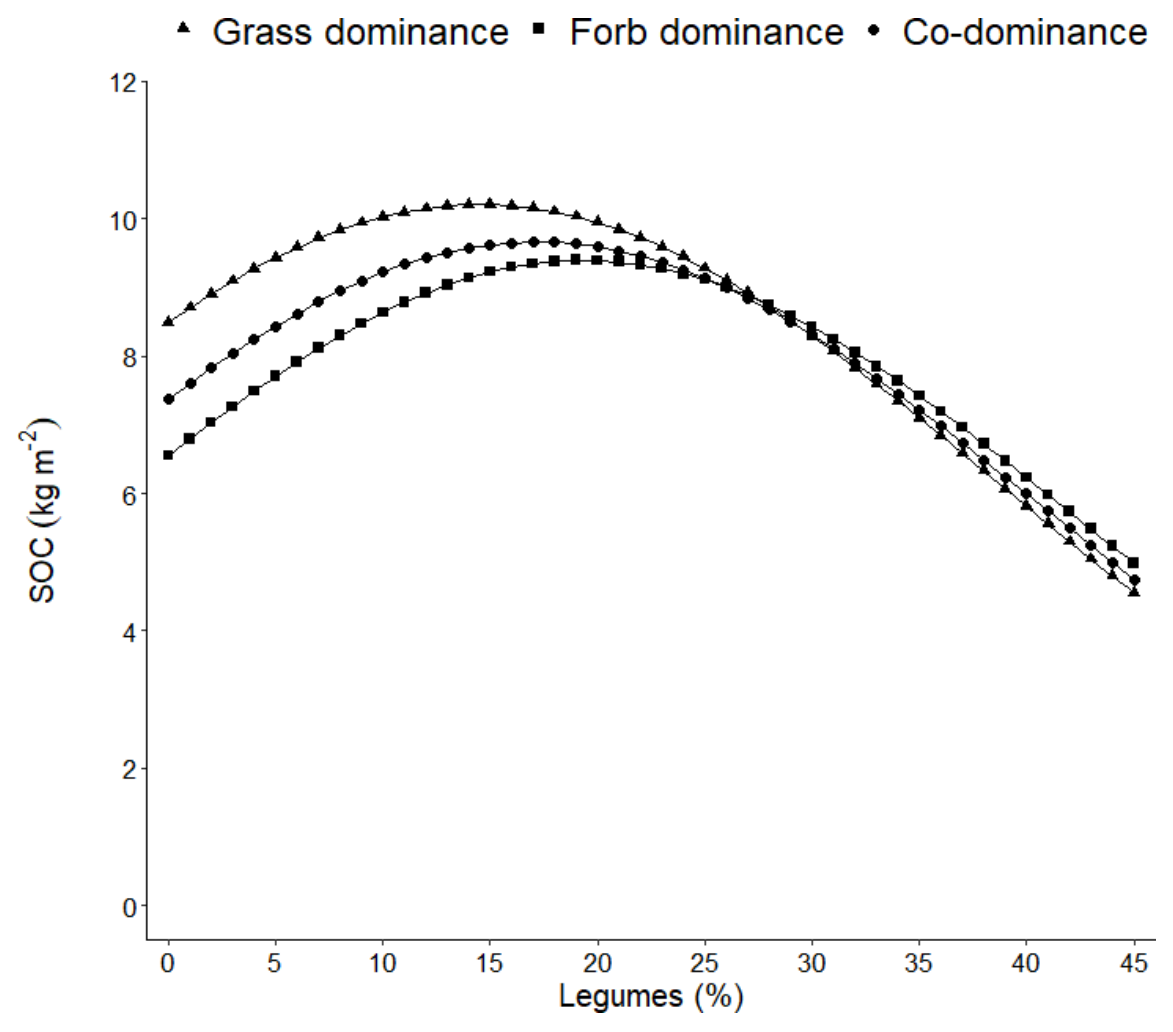

Figure 2: Average values of soil organic carbon stocks (SOC, y axis) depending on legume proportion (x axis). Three curves are shown depending on the composition of legumes, grasses and forbs. Considering the remaining fraction once legume proportion is discounted; triangle: forb:grass proportions of 20:80 (grass dominance); square: forb:grass proportions of 80:20 (forb dominance); circle: forb:grass proportions of 50:50 (co-dominance). Sedges fixed at $0 \%$. Other variables in the model fixed at their mean value.

\begin{tabular}{|c|c|c|c|c|c|c|c|c|c|c|}
\hline $\begin{array}{l}\text { Model } \\
\text { term }\end{array}$ & $\begin{array}{l}\text { Model } \\
\text { term }\end{array}$ & Estimate & Estimate & Estimate & $\mathbf{S E}$ & $\mathbf{S E}$ & $\begin{array}{l}\text { t- } \\
\text { value }\end{array}$ & $\begin{array}{l}\text { t- } \\
\text { value }\end{array}$ & $\begin{array}{l}\text { t- } \\
\text { value }\end{array}$ & $\begin{array}{l}\text { p- } \\
\text { value }\end{array}$ \\
\hline $\begin{array}{l}\text { Plant } \\
\text { guilds }\end{array}$ & $\begin{array}{l}\text { Plant } \\
\text { guilds }\end{array}$ & & & & & & & & & \\
\hline Grasses & Grasses & -0.08 & -0.08 & 0.02 & 0.02 & 0.02 & 0.02 & -3.38 & -3.38 & $\begin{array}{l}1.14 \mathrm{E}- \\
03\end{array}$ \\
\hline Sedges & Sedges & -0.06 & -0.06 & 0.03 & 0.03 & 0.03 & 0.03 & -2.02 & -2.02 & 0.05 \\
\hline Legumes & Legumes & -0.14 & -0.14 & 0.03 & 0.03 & 0.03 & 0.03 & -5.37 & -5.37 & $8.19^{*} 10^{-07}$ \\
\hline Forbs & Forbs & -0.09 & -0.09 & 0.02 & 0.02 & 0.02 & 0.02 & -3.71 & -3.71 & $3.86 * 10^{-04}$ \\
\hline $\begin{array}{l}\text { Grasses } \\
\text { x Sedges }\end{array}$ & $\begin{array}{l}\text { Grasses } \\
\text { x Sedges }\end{array}$ & $\begin{array}{l}-3.15^{*} 10 \\
-04\end{array}$ & $\begin{array}{l}-3.15^{*} 10 \\
-04\end{array}$ & $2.79^{*} 10^{-04}$ & $2.79 * 10^{-04}$ & $2.79^{*} 10^{-04}$ & $2.79^{*} 10^{-04}$ & -1.13 & -1.13 & 0.26 \\
\hline Grasses & Grasses & $8.35^{*} 10^{-04}$ & $8.35^{*} 10^{-04}$ & $2.38^{*} 10^{-04}$ & $2.38^{*} 10^{-04}$ & $2.38^{*} 10^{-04}$ & $2.38^{*} 10^{-04}$ & 3.51 & 3.51 & $7.42^{*} 10^{-04}$ \\
\hline $\mathrm{x}$ & $\mathrm{x}$ & & & & & & & & & \\
\hline Legumes & Legumes & & & & & & & & & \\
\hline Grasses & Grasses & - & - & $6.96^{*} 10^{-05}$ & $6.96^{*} 10^{-05}$ & $6.96^{*} 10^{-05}$ & $6.96^{*} 10^{-05}$ & -0.19 & -0.19 & 0.85 \\
\hline $\begin{array}{l}\mathrm{x} \\
\text { Forbs }\end{array}$ & $\begin{array}{l}\mathrm{x} \\
\text { Forbs }\end{array}$ & $1.29 * 10^{-05}$ & $1.29 * 10^{-05}$ & & & & & & & \\
\hline Sedges & Sedges & - & - & $6.56^{*} 10^{-04}$ & $6.56^{*} 10^{-04}$ & $6.56^{*} 10^{-04}$ & $6.56^{*} 10^{-04}$ & -0.36 & -0.36 & 0.72 \\
\hline $\begin{array}{l}\mathrm{x} \\
\text { Legumes }\end{array}$ & $\begin{array}{l}\mathrm{x} \\
\text { Legumes }\end{array}$ & $2.33^{*} 10^{-04}$ & $2.33^{*} 10^{-04}$ & & & & & & & \\
\hline
\end{tabular}




\begin{tabular}{|c|c|c|c|c|c|c|c|c|c|c|}
\hline $\begin{array}{l}\text { Model } \\
\text { term }\end{array}$ & $\begin{array}{l}\text { Model } \\
\text { term }\end{array}$ & Estimate & Estimate & Estimate & $\mathrm{SE}$ & $\mathrm{SE}$ & $\begin{array}{l}\mathrm{t}- \\
\text { value }\end{array}$ & $\begin{array}{l}\mathrm{t}- \\
\text { value }\end{array}$ & $\begin{array}{l}\text { t- } \\
\text { value }\end{array}$ & $\begin{array}{l}\text { p- } \\
\text { value }\end{array}$ \\
\hline $\begin{array}{l}\text { Sedges } \\
\mathrm{x} \\
\text { Forbs }\end{array}$ & $\begin{array}{l}- \\
2.55^{*} 10^{-04}\end{array}$ & $\begin{array}{l}- \\
2.55 * 10^{-04}\end{array}$ & $\begin{array}{l}- \\
2.55 * 10^{-04}\end{array}$ & $\begin{array}{l} \\
2.55 * 10^{-04}\end{array}$ & $3.04 * 10^{-04}$ & $3.04 * 10^{-04}$ & $3.04 * 10^{-04}$ & -0.84 & -0.84 & 0.41 \\
\hline $\begin{array}{l}\text { Legumes } \\
\text { x Forbs }\end{array}$ & $9.92 * 10^{-04}$ & $9.92^{*} 10^{-04}$ & $9.92 * 10^{-04}$ & $9.92 * 10^{-04}$ & $3.39 * 10^{-04}$ & $3.39 * 10^{-04}$ & $3.39 * 10^{-04}$ & 2.93 & 2.93 & $4.44 * 10^{-03}$ \\
\hline $\begin{array}{l}\text { Environm } \\
\text { vari- } \\
\text { ables }\end{array}$ & $\begin{array}{l}\text { AEntvilronm } \\
\text { vari- } \\
\text { ables }\end{array}$ & nental & & & & & & & & \\
\hline MAT & MAT & 0.18 & 0.18 & 0.07 & 0.07 & 0.07 & 0.07 & 2.49 & 2.49 & 0.01 \\
\hline MSTMAT & MSTMAT & 0.91 & 0.91 & 0.22 & 0.22 & 0.22 & 0.22 & 4.07 & 4.07 & $1.12^{*} 10^{-04}$ \\
\hline MSP & MSP & 0.01 & 0.01 & $5.13^{*} 10^{-03}$ & $5.13^{*} 10^{-03}$ & $5.13^{*} 10^{-03}$ & $5.13^{*} 10^{-03}$ & 2.44 & 2.44 & 0.02 \\
\hline Slope & Slope & 0.01 & 0.01 & $9.60 * 10^{-03}$ & $9.60 * 10^{-03}$ & $9.60^{*} 10^{-03}$ & $9.60 * 10^{-03}$ & 1.28 & 1.28 & 0.2 \\
\hline $\begin{array}{l}\text { Grazing } \\
\text { intensity }\end{array}$ & $\begin{array}{l}\text { Grazing } \\
\text { intensity }\end{array}$ & 8.6 & 8.6 & 2.4 & 2.4 & 2.4 & 2.4 & 3.58 & 3.58 & $6.06^{*} 10^{-04}$ \\
\hline $\begin{array}{l}\text { Slope x } \\
\text { MAT }\end{array}$ & $\begin{array}{l}\text { Slope } x \\
\text { MAT }\end{array}$ & $-\overline{4.59 * 10^{-03}}$ & $-\overline{4.59 * 10^{-03}}$ & $2.04 * 10^{-03}$ & $2.04 * 10^{-03}$ & $2.04 * 10^{-03}$ & $2.04^{*} 10^{-03}$ & -2.25 & -2.25 & 0.03 \\
\hline $\begin{array}{l}\text { Grazing } \\
\text { intensity } \\
\mathrm{x} \text { MAT }\end{array}$ & $\begin{array}{l}\text { Grazing } \\
\text { intensity } \\
\mathrm{x} \text { MAT }\end{array}$ & -0.13 & -0.13 & 0.05 & 0.05 & 0.05 & 0.05 & -2.68 & -2.68 & $9.10^{*} 10^{-03}$ \\
\hline $\begin{array}{l}\text { MSTMAT } \\
\mathrm{x} \\
\text { Grazing } \\
\text { intensity }\end{array}$ & $\begin{array}{l}\text { MSTMAT } \\
\mathrm{x} \\
\text { Grazing } \\
\text { intensity }\end{array}$ & -0.78 & -0.78 & 0.24 & 0.24 & 0.24 & 0.24 & -3.22 & -3.22 & $1.88^{*} 10^{-03}$ \\
\hline $\begin{array}{l}\text { MSP x } \\
\text { Grazing } \\
\text { intensity }\end{array}$ & $\begin{array}{l}\text { MSP x } \\
\text { Grazing } \\
\text { intensity }\end{array}$ & $9.24 * 10^{-03}$ & $9.24 * 10^{-03}$ & $3.56^{*} 10^{-03}$ & $3.56^{*} 10^{-03}$ & $3.56^{*} 10^{-03}$ & $3.56^{*} 10^{-03}$ & -2.6 & -2.6 & 0.01 \\
\hline
\end{tabular}

Table 1: Variables in the final diversity interaction model. 